\title{
Employee Performance Study: Evaluation of Work Motivation as Mediation with Antecedents of Supervision Aspects
}

\author{
Nia Kurniawati ${ }^{1}$ Mokhamad Natsir ${ }^{2 *}$ Harianto Respati ${ }^{2}$ \\ 1.Student in Magister of Management, University of Merdeka Malang, Indonesia \\ 2.Faculty of Economics and Business, University of Merdeka Malang, Indondesia
}

\begin{abstract}
The purpose of this study was to analyze and explain the effect of supervision on employee performance by examining work motivation as an intervening. Research respondents are employees who have the status of civil servants who work at the Malang Regency Transportation Agency, Indonesia. A total of 74 units of analysis were the samples of this study. The analysis technique used descriptive method, and linear regression to confirm a structural equation model that is built. The quantitative approach was chosen to explain the influence of the research variables. Data collection used a questionnaire. The results of this study found that supervision can be a work motivation for employees to complete work on time so that it has an impact on improving employee performance, especially aspects of services to the community, especially transportation services and achievement of local retribution.
\end{abstract}

Keywords: Supervision, Work motivation, Employee performance

DOI: $10.7176 / \mathrm{EJBM} / 12-25-06$

Publication date:September $30^{\text {th }} 2020$

\section{Introduction}

Department of Transportation is an organization implementing the area in the field of transportation which is led by the Head Office and domicile under and responsible to the Regent through the Secretary of the Region, by Law number 22 of 2009, and as stipulated in the Regulation of the Regent of Malang No. 37 the Year 2016, that duty and authority among others are to formulate a policy of technical communications, conducting the affairs of government, and the service of the common areas of transportation, construction, and implementation of the tasks of transportation, supervision, and control, as well as the evaluation and reporting of implementation. Employees are required to be more professional in carrying out the task and understand the duties principal and functions to support the program of activities, working to improve the quality of public services, especially the comfort of the people go by traffic and use of facilities public transportation. Besides, employees are required to always innovate in improving community services, in which the Malang Regency Transportation Office is one of the government agencies that collect taxes/levies in one area. Some of the services to the community that is carried out in achieving regional revenue targets are Motor Vehicle Testing, Terminals and Parking, and Rest Areas in collaboration with related agencies.

To realize the vision and mission of the Department of Transportation, it must be balanced with an service quality improvement, competence, and professionalism of employees in each implementing unit. Coverage area services are very broad, the Department of Transportation only has 9 Units Implementing Technical spread in 33 sub-districts as the operational area. The strengths of the employee still experience a shortage in quantity or quality. One of the efforts to improve performance is supervision that must be carried out more intensively, because of the demand to provide community services and the achievement of PAD targets. The more intensive supervision of the employees implementing it is expected to improve performance because they do surveillance can control every process for the implementation of the task goes according to the plan and regulations that apply. An employee at the Department of Transportation is required to always discipline to time and regulations, committed, maintaining the attitude and look that good, and has a soul Corsa nexus. To improve the performance of employees, it is necessary to search for the factors that course that can take effect. According to Robert La. Mathis and John H.Jackson (2001: 82) factors that affect the performance of individual staff work, namely the ability of those, motivation, support that is received, the existence of the work that they do and ties them with the organization,

Related phenomena of the performance of employees, researchers are interested to do research and want to prove whether the level of supervision of high which will result in performance are high. In fact that the spacious coverage area and the limited number of officials of the supervisory become obstacles supervision can be done in an intensive and the tendency of the largest employee was not noticed or less motivated. By reason that with the theory supporters, worthy of study is quantitative.

Research results from Rosdiana and Indriasih (2016), Susanti (2017), Ubaidillah (2018), Wildayana et al. (2019) proved that supervision affects performance. Supervision also can improve work of motivation with the supervision that does supervision can foster motivation work. Supervision plays a big role in achieving the success of the agency. Winardi (2011:224) states that supervision not only sees something with care and reports the results of activities of supervising but also contains the meaning of repair and straightens it so it reaches the destination 
that is following what their wanted. Since the surveillance is necessary to motivate employees in completing the work according to the specified agencies. The research results of Nurwidyanti et al (2015) and Ubaidillah (2018) prove that supervision affects motivation.

Motivation according to Robbin (2010) is a willingness to put out a high level of effort towards organizational goals, which is conditioned by the ability of that effort to meet individual needs. Work motivation can spur employees to work hard to increase the achievement of agency goals. Indicators of motivation on research using the using indicators of Robbins (2010) which consists of the needs of physiological, needs a sense of safety and safety, the needs of social, needs to be rewards and the need embodiment self. The role of motivation to work is very important because motivation is very related to the performance, If the employee's work motivation is high, then the employee's performance is also high. Conversely, if the employee's work motivation is low, the employee's performance is also low. The research result Rosdiana and Indriasih (2016), Susanti (2017), Ubaidullah (2018), Hasibuan, and Bahri (2018), and Lukertina (2019) proved that the motivation effect on performance.

Based on the study of the interrelationships between supervision, performance employees and the motivation of employees, the function of supervision become fundamental in controlling the work at the level of mobility high. Therefore, is it true that supervision by considering work motivation is a good human resource management strategy to improve employee performance? In this research, a structural equation model is built to answer the problem to be studied.

Paying attention to the phenomenon that occurs that the performance target of the Department of Transportation employees is influenced by intensive supervision through work motivation, which means that the better the implementation of supervision can motivate employees to complete work quickly and precisely so that the PAD target is achieved as expected.

\section{II.Literature Review}

\subsection{Performance Employee}

According to Rivai and Basri (2005), performance is the result or level of success of a person as a whole during a certain period in carrying out a task compared to various possibilities, such as work standards, targets or targets or criteria that have been determined in advance that have been mutually agreed. According to Edison (2016), performance employee is a result of a series of activities for a certain period according to binding policies. Performance that is getting better has a direct effect on the acquisition of performance organizational, with the authority or authority in communication or formal orders that members have when carrying out activities according to their function, a pattern of performance improvement will be formed so that optimal organizational goals are achieved.

\subsection{Supervision}

Siagian (2014) supervisory interview is the process of supervision all organizational activities to ensure that all work in progress is following a predetermined plan. Winardi (2011) argues that supervision is not only looking at things carefully and reporting the results. Activities that involve, but also contain the meaning of improving and rectifying them to achieve goals following what they want.

\subsection{Motivation}

Hasibuan (2010) says that motivation brings movement that raises the spirit of individual work to grow the intention to work by relying on good relationships, streamlined activities, and integrated with everything in the work environment to get satisfaction. This encouragement can bring out the meaning of the level and intensity of workers' efforts in struggling and being diligent in reaching their goals. Otherwise, a lack of minimal encouragement is complicated to get above the encouragement intensity.

\subsection{Research Concept Framework}

In Figure 1, it explains that work motivation serves as a mediation between employee supervision and performance and explains the impact of the direct influence between supervision and employee performance.

Figure 1. Structural Equation Modeling

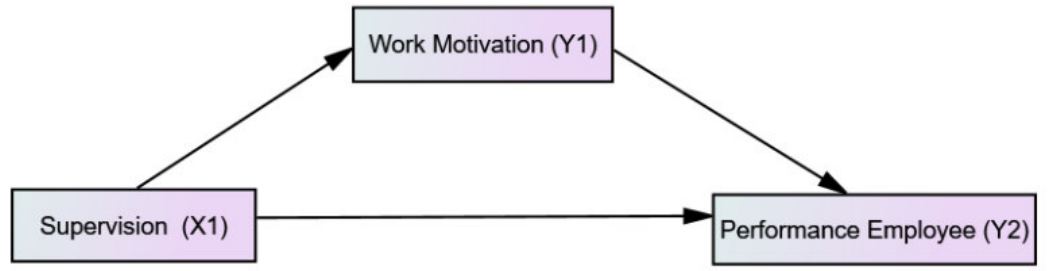




\section{Research Method}

\subsection{Research Design}

This research design used a quantitative method with two research hypotheses. Descriptive analysis was employed to explain the description of each variable studied and multiple linear regression analysis was employed to determine the effect between the variables being tested. The questionnaire was employed to collect primary data. Respondents only choose five answers according to a Likert Scale in choice one is strongly disagree, two disagrees, three is neutral, four agrees, and five strongly agrees.

\subsection{Population and Sample}

The research was conducted in the period 29 June 2020 to 5 August 2020. Research respondents were all personnel who served in the main office and UPT totaling 267 people. The Slovin formula was employed to determine the sample, to obtain a sample of 74 respondents who are civil servants from a population of 267 employees. The sampling technique used simple random sampling with the consideration that all employees have the same opportunity to answer the research questionnaire.

\subsection{Variable and Indicator}

Supervision is measured by three indicators, in terms of input control, behavior control, and expenditure control. Motivation is measured by five indicators, namely physiological needs, safety needs, social needs, reward needs, and self-actualization needs. Meanwhile, performance employee is measured by six indicators, namely quality of work, the quantity of work, timeliness of work, effectiveness, independence, and work commitment. The structure of the variables, indicators, and the number of research instruments is shown in Table 1

Table 1. Variable, Indicator and Research Instrument

\begin{tabular}{|l|c|}
\hline Variable dan Indicator & The total of instrument \\
\hline Supervision $\left(\mathrm{X}_{1}\right)$ & 2 \\
\hline Income Control $\left(\mathrm{X}_{1.1}\right)$ & 2 \\
\hline Behavior Control $\left(\mathrm{X}_{1.2}\right)$ & 2 \\
\hline Expenditure Control $\left(\mathrm{X}_{1.3}\right)$ & 3 \\
\hline Motivation $\left(\mathrm{Y}_{1}\right)$ & 3 \\
\hline Physiological needs $\left(\mathrm{Y}_{1.1}\right)$ & 3 \\
\hline Safety needs $\left(\mathrm{Y}_{1.2}\right)$ & 3 \\
\hline Social needs $\left(\mathrm{Y}_{1.3}\right)$ & 3 \\
\hline Esteem needs $\left(\mathrm{Y}_{1.4}\right)$ & \\
\hline Self-Actualization needs $\left(\mathrm{Y}_{1.5}\right)$ & 3 \\
\hline Performance Employee $\left(\mathrm{Y}_{2}\right)$ & 3 \\
\hline Quality of Work $\left(\mathrm{Y}_{2.1}\right)$ & 3 \\
\hline Quantity of Work $\left(\mathrm{Y}_{2.2}\right)$ & 3 \\
\hline Timeliness ( $\left.\mathrm{Y}_{2.3}\right)$ & 3 \\
\hline Effectiveness $\left(\mathrm{Y}_{2.4}\right)$ & 3 \\
\hline Dependability $\left(\mathrm{Y}_{2.5}\right)$ & 39 \\
\hline Commitment of Work $\left(\mathrm{Y}_{2.6}\right)$ & Total \\
\hline
\end{tabular}

\section{Research Findig}

\subsection{Respondent Profile}

Malang Regency Transportation Service located in Kepanjen City is a regional apparatus organization that carries out Regional Government affairs in the transportation sector including safety, traffic, transportation, terminals, and parking, as well as the Technical Implementation Unit (UPT) of Transportation and UPT of Motor Vehicle Testing which scattered in several districts. Researchers measure respondents' perceptions of supervision and motivation as an intervening variable on employee performance. The data collected were as many as 74 units of questionnaires. Respondent profiles are presented in Table 2.

\section{Table 2. Respondent Profile}

\begin{tabular}{|l|l|l|l|}
\hline \multicolumn{1}{|c|}{ Age } & \multicolumn{1}{|c|}{$\%$} & \multicolumn{1}{|c|}{ Level of Education } & \multicolumn{1}{c|}{$\%$} \\
\hline $25-35$ & 9,5 & S2 & 6,8 \\
\hline $36-46$ & 43,2 & S1 & 29,7 \\
\hline $47-58$ & 47,3 & Diploma 3 & 1,4 \\
\hline \multicolumn{1}{|c|}{ Gender } & $\%$ & Diploma 2 & 4,1 \\
\hline Male & 91,9 & High school/ vocational school & 55,4 \\
\hline Female & 8,1 & Junior high school & 2,6 \\
\hline
\end{tabular}


Male respondents were more than women because the work demands required more activities with high mobility outside the office building, especially control, supervision, order of the parking terminal and collection of user fees, and the age range of 47 to 58 was more, which meant that more employees were approaching the retirement age limit, there are more SMA / SMK education levels, which means more employees occupy executive positions following their educational qualifications.

\subsection{Result of Analysis Description}

Analysis of data processing used the SPSS (Statistical Package for Social Science) program. There are three variables, 14 indicators and a total instrument of 39 items. The results of the validity and reliability testing for 39 items proved to be valid from the probability of each instrument not exceeding the $5 \%$ error rate, meaning that the respondent understood the meaning of the measurements contained in the questionnaire (see Appendix). The results of the research instrument reliability test showed a good level of reliability as evidenced by the Cronbach Alpha value not exceeding the $r$ table value $(0.181)$. The results of the descriptive analysis for each research variable, indicators, and 39 research instruments are presented in the appendix.

The description of the respondent's perception can be analyzed from the average value produced by the indicators and instrument items. The indicator that best describes supervision is that respondents tend to strongly agree about the leadership inspecting employees. The indicator that best describes work motivation is that respondents tend to agree strongly about motivation formed by physiological needs, security needs, social needs, reward needs, and self-actualization needs, the main thing that supports motivation is the need for self-actualization reflected in every employee being given development opportunities. self. Indicators that best describe employee performance, respondents tend to strongly agree that employee performance is shaped by work quality, work quantity, timeliness, effectiveness, independence, and work commitment, where the main thing that can improve employee performance is the quality of work reflected in the respondent's responsibility for every implementation of the tasks assigned to them.

\subsection{Results of Linear Regression Analysis}

The structural equation model was built by regressing twice, with the regression model equation being as follows:

The first multiple linear regression model: $\mathrm{Y} 1=0.719 \mathrm{X} 1+\mathrm{e} 1$

Second multiple linear regression model: $\mathrm{Y} 2=0.489 \mathrm{X} 1+0.274 \mathrm{Y} 1+\mathrm{e} 2$

The results of the structural equation model are presented in Figure 2.below:

Figure 2. Result of Structral Equation Modeling

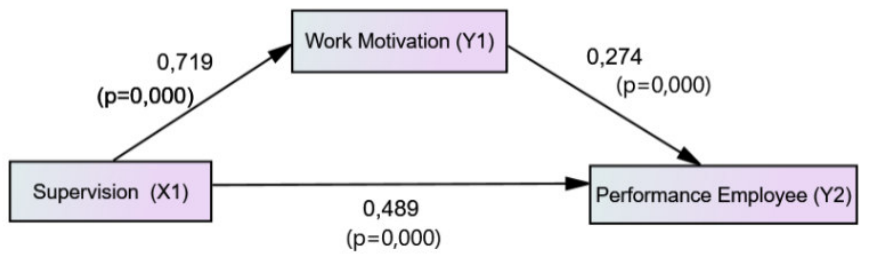

There are three regression coefficients in the structural equation model above. The supervision regression coefficient shows a significant effect on employee performance, while the regression coefficient of work motivation as an intervening is not significant. The results of the path analysis evaluation are presented in Table 3.

Table 3. Path Analysis Result

\begin{tabular}{|l|c|c|c|}
\hline \multicolumn{1}{|c|}{ Variable } & $\begin{array}{c}\text { Direct } \\
\text { Effect }\end{array}$ & Indirect Effect & $\begin{array}{c}\text { Total } \\
\text { Effect }\end{array}$ \\
\hline Supervision to Work Motivation & 0,719 & - & - \\
\hline Supervision to Performance Employee & 0,489 & - & - \\
\hline Work Motivation to Performance Employee & 0,274 & - & - \\
\hline $\begin{array}{l}\text { Supervision to Work Motivation and to Performance } \\
\text { Employee }\end{array}$ & 0,489 & $\begin{array}{c}0,719 \text { X 0,274 } \\
0,197\end{array}$ & 0,686 \\
\hline
\end{tabular}

\section{Discussion}

From the first hypothesis, supervision has an effect on work motivation, which means that as better as supervision carried out can increase work motivation, with behavioral control indicators reflected in the evaluation of employee work results. With this supervision, employees strive to maximize their potential, so that they are motivated to provide the best work results. The results of this study are in line with Nurwidyanti et al (2015) and Ubaidillah (2018) stated that supervision affects work motivation.

Supervision affects employee performance, which means that as better as supervision is applied, it can 
improve employee performance. Supervision has an important role in preventing irregularities or errors in the process of implementing assigned tasks so that employee performance can be improved both in quality and quantity. The results of this study are consistent with Rosdiana and Indriasih (2016), Susanti (2017), Ubaidilla (2018), and Wildayana et al (2019) stated that supervision affects employees performance.

Work motivation has a significant effect on employee performance, where the need for self-actualization has a substantial contribution to improving performance, this is reflected in every employee is given the opportunity for self-development. Employees with a high level of motivation will have a desire to work more optimally because they will feel satisfied when they achieve mutually agreed performance targets. The results of this study support Rosdiana and Indriasih (2016), Susanti (2017), Ubaidillah (2018), Hasibuan, and Bahri (2018), Parashakti and Lukertina (2019) who state that work motivation affects employee performance.

The hypothesis confirmation of supervision affects employee performance through motivation, that supervision can improve employee performance if supported by employees who have high work motivation. Employees will then be more enthusiastic about improving the performance which is shaped by the quality of work, which was evaluated in the responsibility of employees for carrying out their duties. Supervision is carried out so that the implementation of tasks is carried out according to plan, can find out, correct, and evaluate errors during the process. Leaders as supervisors provide guidance and direction that will motivate employees to improve performance, to achieve maximum targets following applicable regulations. The results of this study are in line with research by Ubaidillah (2018) proves that supervision affects employee performance through motivation.

Confirmation of this hypothesis proposes more intensive supervision because employees become more confident in carrying out their duties so that they are motivated to be responsible by being allowed to develop their potential, thus trying to improve the quality and quantity of performance.

\section{Conclusion and Recommendation}

The results showed that the supervision of behavior control is the main thing, with the evaluation of employee work results. Motivation is supported by the need for self-actualization of employees, namely by providing opportunities to develop their potential. Employee performance is formed by work quality, work quantity, timeliness, effectiveness, independence, and work commitment. Quality of work is the main thing with the form of employee responsibility in carrying out assigned tasks following applicable regulations. Supervision can motivate employees to complete work quickly and precisely. Employee performance can be improved if supervision is carried out effectively to motivate employees to complete work according to procedures and achieve performance targets. For further researchers, it is suggested to add variables other than the variables that have been used in this study, so that it can be predicted that they will affect employee performance, such as leadership and job satisfaction.

\section{REFERENCES}

Azevedo R.E and Akdere. 2010. The Economics of Utility, Agency, Theory, and Human Resource Development. Advances in Developing Human Resources. Vol.10. No.6.pp 817-833

Edison, Emron, Anwar, Yohny and Komariyah, Imas. 2016. Human Resource Management. First edition Alfabeta. Bandung.

George R. Terry, 2006. The Management Principles. Jakarta: Bumi Aksara Publisher

Ghozali, Imam, 2007. Multivariate Analysis Application with SPSS Program, Universitas Diponogoro, Semarang Gujarati, Damodar N. 2006. The Fundamental Econometrics. Jakarta : Erlangga Publisher

Handoko, T.Hani.2001. The Personnel Management and Human Resources, Second edition. BPFE Yogyakarta : Yogyakarta

Harbani, Pasolong.2013.The Bureaucratic of Leadership. Bandung : CV.Alfabeta

Hasibuan, Malayu. 2008. Fundamental Management, Definitions, and Problems. Jakarta: PT Bumi Aksara. 2010. Organization and Fundamental Motivation for Increasing Productivity. Fifth edition . Bumi Aksara, Jakarta.

Hasibuan, Siti Maisarah and Syaiful Bahri. 2018. The Influence of Leadership, Work Environment and Work Motivation on Performance. Maneggio: Scientific Journal of Master of Management.Vol.1.No.1.pp 71-80.

Iqbal., S. 2014.The Impact of Organizational Commitment, Job Satisfaction, Job Stress and Leadership Support on Turnover Intention in Educational Institutes, International Journal of Human Resource Studies, Vo.4.No.2.

James, L.John. 2008. Organizations. Fourth edition. Jakarta: PT. Gelora Aksara Pratama

Kasmir. 2016. Human Resource Management (Theory and Practice).Jakarta: PT Raja GrafindoPersada.

Mangkunegara, A.A Anwar Prabu. 2006. Human Resource Management. Remaja Rosda Karya. Bandung Publisher.

2002. Human Resource Management.Company. Remaja Rosdakarya. Bandung.

2004. Human Resource Management. Bandung: Remaja Rosda Karya. 2009. The Evaluation of Human Resources Performance. Refika Aditama. Bandung. 
2016. Company Human Resource Management. Bandung : PT. Remaja Rosdakarya

Martoyo, Susilo. 2000. Human Resource Management. BPFE - JogJakarta.

Mulyadi. 2007. Planning and Management Control Systems. Jakarta: Salemba Empat.

Nurwidyanti, Ferisca, Marnis and Marzolina. 2015. The Effect of Supervision and Organizational Climate on Motivation and Work Discipline of Employees at the Regional Secretariat General Bureau Office of Riau Province. Journal of Tepak Business Management. Vol.7.No.3.pp420-436.

Parashakti, Ryani Dhyan and Lukertina Lukertina. 2019. Is Employee's Performance Influenced by Incentives and Work Motivation?. The Advances in Economics, Business and Management Research. Vol.120.pp37-39.

Malang Regent Regulation. 2016. Number 37 of 2016 concerning Position, Organizational Structure, Duties and Functions and Work Procedures of the Transportation Service.

Priyatno, Duwi. 2013. Correlation, Regression, and Multivariate Analysis with SPSS. Yogyakarta : Gava Media.

Rivai Zainal, Veithzal.2015. Human Resource Management for Companies from Theory to Practice, Jakarta:PT Raja Grafindo Persada.

Robbins, Stephen P and Mary Coulter. 2010. Management translated by Bob Sabran, Wibi Hardani. Tenth edition.Jakarta: Erlangga.

Rosdiana, Dessi and Dewi Indriasih. 2016. The Effect of Work Environment, Supervision, Competence and Motivation on Performance with Compensation Variables as Intervening Variables for Tegal City Dishubkominfo Employeesl. Multiplier: Jurnal Magister Manajemen. Vol.1. No. 1.pp 57-65.

Sanusi, Anwar. 2014. Business Research Methodology.Jakarta: Salemba Empat.

Siagian, Sondang P.2014. Human Resource Management Jakarta: BumiAksara.

Simamora, Henry. 2011. Human Resource Management. STIE YKPN. Yogyakarta.

Sugiyono. 2018. Quantitative Research Methods, Qualitative, and R \& D. Bandung: Alfabeta.

Susanti, Ike. 2017. The Influence of Work Discipline, Supervision and Motivation on Employee Performance at PT. MMW In Sidoarjo. Jurnal Penelitian Ekonomi dan Akuntansi. Vol.11.No.2.pp 425 - 437.

Sutrisno, Edy.2011. The Human Resource Management. Kencana. Jakarta.

Ubaidillah. 2018. The Role of Motivation as Mediation on the Relationship between Supervision and Employee Performance (Case Study at PT. Asuransi Central Asia Cab. Jambi). Exist: Scientific Journal of Economics and Business. Vol.9. No. 2.pp161-164.

Law No. 9 of 2015 concerning the Second Amendment to Law No. 23 of 2014 concerning Regional Government.Wibowo. 2011. Manajemen Kinerja. Edisi Ketiga. Jakarta: PT Raja Grafindo Persada.

Wildayana, Wildayana, Machasin and Yulia Efni. 2019. The Effect of Internal Supervision and Communication Influence on Job Satisfaction and its Impact on Employee Performance in the Public Works and Spatial Planning Office of Riau Province. Bahtera Inovasi. Vol.3. No.1.pp13-27.

Winardi. 2011. Motivation. Jakarta: PT. Raja Grafindo Persada. 